A 5600-yr history of changing vegetation, sea levels and human impacts from the Black Sea coast of Georgia

Connor, S.E., Thomas, I. and Kvavadze, E.V.

This is a draft version of a manuscript published in The Holocene 17: 25-36 (2007). Please note that there may be differences between this version and the final published version. The authors will be happy to provide copies on request. 


\title{
A 5600-year history of changing vegetation, sea levels and human impacts from the Black Sea coast of Georgia
}

\author{
Simon E. Connor ${ }^{1 *}$, Ian Thomas ${ }^{1}$ and Eliso V. Kvavadze ${ }^{2}$ \\ ${ }^{1}$ School of Anthropology, Geography and Environmental Studies, University \\ of Melbourne, Victoria 3010, Australia. \\ Georgia. \\ ${ }^{2}$ L. Davitashvili Institute of Palaeobiology, 4 Niagvris St., Tbilisi 0108,
}

Keywords: Colchis, Caucasus, pollen, charcoal, sea level rise, archaeology

\section{Abstract}

Mid-late Holocene pollen evidence from the Ispani-II Sphagnum bog in lowland Western Georgia shows that 4500 years ago Castanea (chestnut)-dominated woods rapidly declined to be replaced by alder swamps, and later, during the $1^{\text {st }}$ millennium BC, by open, marshy landscapes in which fire played a prominent part. Around 1900 years ago, Sphagnum blanket bog encroached on the marshes and dense Fagus-Carpinus (beech-hornbeam) forest enveloped the surrounding land. This vegetation remained until the mid- $20^{\text {th }}$ century, when forests were clear-felled and marshes were drained for large-scale, mechanized agriculture. Previous studies have

\footnotetext{
* Corresponding author. E-mail: connorse@unimelb.edu.au; fax: +61 393494218
} 
emphasized climate's governing role in setting the course of Holocene vegetation development in Colchis, but our results provide little support for this hypothesis. To a much greater degree, episodes of coastal subsidence, sea level rise and human impact have shaped the vegetation history of coastal Western Caucasus.

\section{Introduction}

Colchis, the lowland of Western Georgia facing the Black Sea, is perhaps the most important refugium of Tertiary relict plants in Eurasia (Denk et al., 2001; Kikividze and Ohsawa, 2001; Berg, 1950). Colchis, known as Kolkheti in Georgian and Kolkhida in Russian, is a part of the Caucasian refugium, which also includes the southern coasts of the Black and Caspian Seas. It is one of three major locations in Western Asia where thermophilous plants survived the cold and aridity of glacial periods (Röhrig, 1991). During the last glacial maximum, while most of Eurasia was covered by steppe and tundra vegetation, mixed deciduous and coniferous forests survived in Western Georgia (Tarasov et al., 2000). As a result, species-rich Colchic forests combine elements of Mediterranean, Euro-Siberian, Euxinian, Hyrcanian and East Asian floras (Nakhutsrishvili, 1999).

Colchis is perhaps best known as the legendary destination of Jason and the Argonauts. But far from being a mythical land, abundant archaeological evidence shows that this coastal plain was very densely populated during the $1^{\text {st }}$ millennium $\mathrm{BC}$ and earlier, with highly-developed metallurgy from the mid- $2^{\text {nd }}$ millennium $\mathrm{BC}$ and Greek colonies from the $6^{\text {th }}$ century BC (Lordikipanidze, 1994; Tsetskhladze and 
Treister, 1995). Prehistoric settlements of the Black Sea coast of Colchis were of an unusual sort, inasmuch as they were situated on artificial mounds reclaimed from the wetlands and connected by canals.

The major force of environmental change in the Black Sea region is the sea itself. It existed as a huge lake, isolated from the Mediterranean, during much of the Pleistocene and early Holocene (Fedorov, 1988). The proposition of a great earlyHolocene deluge in 7550 cal. yr BP has initiated scholarly debate of biblical proportions (e.g. Ryan et al., 1997; Aksu et al., 1999; Ballard et al., 2000; Uchupi and Ross, 2000; Görür et al., 2001; Mudie et al., 2002; Atanassova, 2005). Even in the time period encompassed by this paper, the Colchis coastline has experienced a number of marine transgressions and regressions. Most significant were the NewBlack-Sea transgression (6500-4500 cal. yr BP), the Phanagorian regression (45002000 cal. yr BP) and the Nymphaean transgression of 2000-1000 cal. yr BP (Chepalyga, 1984; Tvalchrelidze et al., 2004). These Black Sea level changes were caused by tectonic subsidence, dune building, coastal sedimentation, climate change and eustatic sea level variations, and have left their imprint on the landscapes and settlement patterns of the Black Sea coast. In Colchis, the Nymphaean transgression paludified low-lying ground, drowned a number of settlements and formed extensive alder swamps and peat bogs (Dzhanelidze, 1980).

The peat deposits and history of Tertiary-relict plants in the Colchis lowland have attracted the attention of palynologists for 75 years. Much work has focussed on 
the pre-Holocene sediments of Western Georgia, providing evidence for the existence of Tsuga, Sequoia, Cryptomeria, Carya, Taxodium, Aesculus and other taxa prior to their extinction during Pleistocene glacial periods (Tumajanov, 1971; Shatilova and Mchedlishvili, 1980). Investigation of Holocene sediments in Colchis began in the early 1930s (Dokturovskii, 1931, 1936), and since then Neishtadt (1957), Neishtadt et al. (1965), Sluka (1973), Kvavadze (1982), Serebryannyi et al. (1984), Kvavadze and Dzheiranashvili (1987) and Kaffke et al. (2002) have provided data on the vegetation history of the Colchis coastal plain. Neishtadt (1957) condensed this history into three phases of forest development: a Castanea phase, a transitional phase, and a Fagus-Carpinus phase.

Despite a long history of diverse and independent investigation, the interconnections between human settlements, sea level oscillations, relict taxa and Holocene vegetation changes along the eastern Black Sea coast are still obscured by a lack of high-quality data, especially in relation to chronology. In this paper, we present new data on the vegetation and sedimentary history of the Colchis coastal lowland and question the long-held view (Neishtadt, 1957; Sluka, 1973; Dzhanelidze, 1980; Kvavadze, 1982) that its three-phase vegetation development was predominantly the product of Holocene climatic changes. 


\section{Study area}

\section{Geography and climate}

Colchis is a vast alluvial lowland, broadly triangular in shape (Figure 1). It is bordered to the north by the Caucasus Mountains (Kodori, Egrisi and Racha Ranges). To the east it narrows toward the Likhi Range, the watershed between the Black and Caspian Sea basins. The southern border of Colchis is formed by the Anticaucasus Mountains (Meskheti and Shavsheti Ranges).

The Colchis lowland is traversed by large rivers draining the southern slopes of the glaciated Caucasus Mountains (e.g. Rioni, Qvirila, Tskhenis-Tsqali and Enguri Rivers) and smaller rivers flowing from the Meskheti Range (e.g. Supsa, AcharisTsqali and Natanebi Rivers). The topography is muted and much of the plain is less than a hundred metres above sea level. Geologically, most of the plain is made of Quaternary alluvial and fluvioglacial sediments, derived from massifs of Eocene volcanics in the Anticaucasus and the complex folds of the Main Caucasus Range. Soils on the foothills are relatively fertile krasnozems and leached podzols, while the soils of the plains are alluvial and often waterlogged (AN GSSR, 1964).

A coastal strip runs for about $100 \mathrm{~km}$ from Kobuleti in the south to Ochamchire in the north and has extensive peat-bog development (Figure 2). Many of these wetlands have been drained in the past 80 years for conversion to agricultural land (Ketskhoveli, 1959; Badenkov et al., 1990). 
The climate of Colchis is 'oceanic' (Rübel, 1914) and heavily influenced by moist westerlies originating over the Black Sea. It is characterized by high rainfall and humidity year-round, and experiences fewer frosts than the more continental parts of Georgia (Walter, 1974). Most of the Colchis lowland receives more than $1500 \mathrm{~mm}$ precipitation per annum. The seaside town of Kobuleti in southern Colchis receives $2365 \mathrm{~mm}$. Winter temperatures are mild (January average is $5{ }^{\circ} \mathrm{C}$, absolute minimum $-4{ }^{\circ} \mathrm{C}$ ) and summers are warm (July average is $23{ }^{\circ} \mathrm{C}$, abs. max. $35^{\circ} \mathrm{C}$ ) (AN GSSR, 1964).

\section{Vegetation}

Colchic vegetation is characterized by great diversity, with over 50 arboreal species and 80 herbaceous species (Kolakovskii, 1961). The moist temperate climate of Colchis has ensured the survival of a number of Tertiary-relict plants, studied in some detail by Denk et al. (2001). They include Alnus barbata, Carpinus betulus (syn. C. caucasica), Castanea sativa, Diospyros lotus, Fagus orientalis, Pterocarya fraxinifolia, Quercus hartwissiana, Q. iberica, Zelkova carpinifolia and many more.

Lianas are very common, especially Hedera colchica, $H$. helix, Dioscorea caucasica, Tamus communis, Periploca graeca, Smilax excelsa, Clematis vitalba and Vitis vinifera subsp. sylvestris (Nakhutsrishvili, 1999). Another characteristic of Colchic forests is their evergreen understorey, with Buxus colchica, Laurocerasus officinalis, Ruscus aculeatus, R. hypophyllum, Ilex colchica etc. (Denk et al., 2001; Nakhutsrishvili, 1999). 
The wetland flora of southern Colchis is interesting in that it contains a number of Boreal taxa - Menyanthes trifoliata, Drosera rotundifolia, Rynchospora alba, Carex lasiocarpa and Osmunda regalis (Ketskhoveli, 1959). Peat bogs are dominated by Sphagnum imbricatum, S. papillosum, S. palustre, S. rubellum and moor-grass, Molinia litoralis. Rhododendron ponticum and $R$. luteum grow on the bog surface, and Frangula alnus, Vaccinium arctostaphylos, Alnus barbata, Pteridium tauricum and Rubus spp. occur at the bog margins (Akhalkatsi et al., 2004; Joosten et al., 2003).

Due to rapid development of the Colchis coastal lowlands for so-called 'subtropical' horticulture in the middle $20^{\text {th }}$ century, however, very little of the original vegetation cover survives today (Figure 2; Walter, 1974; Badenkov et al., 1990; Gvilava, 1996).

\section{Site and methods}

The study site, Ispani-II (Figure 2), is located at the northern end of Kobuleti Township, in southern Colchis. It is part of the South Colchis wetland system which includes the neighbouring Ispani-I wetland, now drained. The peat surface of the Ispani-II coring site is approximately two metres above sea level and $1.5 \mathrm{~km}$ from the sea shore $\left(41^{\circ} 51^{\prime} 47^{\prime \prime} \mathrm{N} ; 41^{\circ} 48^{\prime} 4^{\prime \prime} \mathrm{E}\right)$. The same peat-bog was previously investigated in the 1930s (Dokturovskii, 1936), but since no radiocarbon dates are available for that pollen record, it was necessary to obtain new data at a higher taxonomic and sampling resolution. 
The Ispani-II core was collected in September 2003 using a D-section corer, 5 $\mathrm{cm}$ in diameter and $50 \mathrm{~cm}$ in length. Sediments were cored to a depth of $950 \mathrm{~cm}$ below the living Sphagnum and subsampled in the field. Moisture and organic content determinations were made according to the method of Bengtsson and Enell (1986). Pollen extraction involved $10 \% \mathrm{HCl}$ treatment, boiling in $10 \% \mathrm{KOH}$, heavy liquid separation (sodium polytungstate, s.g. 2.0) and standard acetolysis (Moore et al., 1991). The presence of Alnus and Poaceae macrofossils in the sediment core (Table I) suggested that they were locally occurring at the time of pollen deposition, so we have excluded these taxa from the dryland pollen sum. However, because Alnus occurs in mixed Colchic forests as well as in marshes and Poaceae also includes many terrestrial types, we account for this in the discussion below.

Carbonized particles were quantified by point-count estimation (Clark, 1982). Three accelerator mass spectrometer (AMS) radiocarbon ages were obtained and calibrated ages (cal. yr BP) determined using CALIB (Stuiver and Reimer, 1993). We analysed pollen data numerically with the aid of debugged Detrended Correspondence Analysis (DCA) (Hill, 1979; Oksanen and Minchin, 1997).

\section{Results}

\section{Sediment lithology and chronology}

Three lithological units can be identified in the Ispani-II sediments (Table I). The lowermost unit (Is-1: 950-690 cm) consists of clay-rich sediments, containing 
both sandy and organic layers, charcoal and macrofossils (Table I). Its organic content varies between 9\% and 23\% (Figure 3). The second unit (Is-2: 690-510 cm) is higher in organic content (32-51\%) with a greater concentration of Alnus macrofossils. It is darker in colour and composed of decayed sedge, grass and wood. Above these gyttja layers, the sediment changes to Sphagnum peat (Is-3, Is-4: 510-0 $\mathrm{cm})$. The most striking characteristic of the peat comprising this unit is that unhumified Sphagnum remains dominate the entire five-metre profile. The organic content of this unit varies between 90 and 98\% (Figure 3).

The three AMS radiocarbon ages (Table II) show that the clayey sediments of unit Is- 1 accumulated between 5600 and 4500 cal. yr BP at a rate of about $0.25 \mathrm{~cm} . \mathrm{yr}^{-}$ $\left.{ }^{1}\right)$. The gyttja layers (Is-2) followed and accumulated slowly $\left(\sim 0.06 \mathrm{~cm} \mathrm{yr}^{-1}\right)$ until approximately 1900 cal. yr BP, when Sphagnum peat (Is-3, Is-4) began to form. An additional radiocarbon age from Ispani-II material provided by Joosten et al. (2003) shows that Sphagnum peat accumulated slowly from 1900 to 1000 cal. yr BP (0.13 cm.yr $\left.{ }^{-1}\right)$, but rapidly thereafter $\left(0.43 \mathrm{~cm} \cdot \mathrm{yr}^{-1}\right)$.

\section{Pollen diagram}

The Ispani-II pollen diagram is subdivided into four pollen assemblage zones (Figure 3), statistically determined by optimal splitting by information content (Birks and Gordon, 1985; Bennett, 2002), and which correspond to the lithological units discussed above. 
In the first zone (Is-1), spanning the period from 5600 to 4500 cal. yr BP, Castanea pollen dominates and, toward the end of the zone, peaks at $85 \%$ of dryland pollen. This occurs against a background of arboreal pollen in which Pinus, Quercus, Fagus, Carpinus betulus-type and Corylus are more or less equally abundant. Percentages of Salix, Cannabis-type and Rhododendron pollen and fern spores are greater in this zone than in the remainder of the record. Alnus proportions oscillate between $20 \%$ and $70 \%$ of total pollen. Wetland and aquatic pollen types include Lythrum salicaria-type, Cyperaceae, Sparganium erectum-type and Trapa. Nonpollen palynomorphs of Spirogyra, Tetraploa, Pediastrum and Ceratophyllum (see van Geel, 1978) are found solely in the middle of this zone. Charcoal is well represented $\left(0.05-0.41 \mathrm{~cm}^{2} \cdot \mathrm{cm}^{-3}\right)$.

The second pollen zone (Is-2) encompasses the period from 4500 to $1900 \mathrm{cal}$. yr BP. Castanea percentages decline dramatically at the commencement of the zone, and continue to decline throughout. Although this is matched to some extent by modest increases in Fagus, Carpinus betulus and especially Quercus, the most important increase is in the pollen of shrubs: Frangula alnus and Rhamnus-type (up to 19\%), Viburnum (4\%), Sorbus-type (1.5\%) and Juniperus (1\%). Pollen of the lianas, Hedera helix (up to 3\%) and Vitis vinifera (up to 1\%), is also best represented in this zone. Alnus pollen peaks at the beginning of the zone, but rapidly declines from $87 \%$ to $27 \%$ of total pollen as non-arboreal pollen percentages rise to $20 \%$ and charred particles reach very high concentrations $\left(3.1 \mathrm{~cm}^{2} . \mathrm{cm}^{-3}\right)$. Aquatic pollen of Callitriche 
and Potamogeton appears during the first half of zone Is-2, to be replaced by Sphagnum spores, Poaceae, Cyperaceae and Osmunda regalis pollen in the upper half.

At the beginning of the third zone (Is-3), dated to 1900 cal. yr BP, Quercus declines somewhat as Fagus and Carpinus betulus-type increase. This zone sees the first occurrences of Juglans, Olea europaea, Morus, Buxus, Platanus and Pterocarya pollen. The latter rises to a considerable peak (18\%) in the lower part of the zone, at the same time as Castanea pollen all but disappears. Although non-arboreal pollen percentages are reduced relative to zone Is-2, types such as Rumex, Plantago lanceolata, P. major-type, Filipendula, Urtica and Pteridium all increase in zone Is-3. Sphagnum spores, associated with fungal spores of Tilletia sphagni, are well represented throughout the third zone and Lycopodiella inundatum spores also appear in abundance (up to $19 \%$ ) between $500-425 \mathrm{~cm}$.

The final zone (Is-4), like the second, sees an overall decline in arboreal pollen. Fagus, Carpinus betulus, Quercus, Ulmus, Fraxinus, Zelkova and Pterocarya pollen percentages diminish, while Pinus and Castanea increase slightly and Corylus remains unchanged. The transition from zone Is-3 to Is-4 is accompanied by a considerable charcoal peak $\left(0.7 \mathrm{~cm}^{2} . \mathrm{cm}^{-3}\right)$, declining Alnus percentages and increased inorganic sediment inputs. Pollen of introduced plants dominates this zone Cryptomeria pollen reaches 48\% and Ambrosia 15\%. Zea mays appears also.

DCA (Figure 3) identified two prevailing trends in the dryland pollen data. The first trend is positively-correlated with Castanea, Filicales, Salix, Cannabis-type 
and Sinapsis-type (Brassicaceae); while negatively-correlated with Fagus, Carpinus betulus-type, Corylus, Plantago lanceolata-type, Juglans and several other arboreal taxa. It represents a change from Castanea-dominated woods to mixed forests. The second DCA axis is positively-correlated with Cryptomeria, Ambrosia-type, Filicales, Castanea and a number of herbaceous taxa; and negatively-correlated with Fagus, Carpinus betulus, Ulmus, Fraxinus and most arboreal taxa. This, then, probably represents the degree of forest cover or landscape openness.

\section{Discussion}

\section{Vegetation history}

The three Holocene stages of Colchic vegetation development proposed by Neishtadt (1957) are clearly reflected in Zones Is-1, Is-2 and Is-3 of the new Ispani-II pollen diagram. The first zone represents the 'Castanea phase', the second zone the 'transitional phase', and the third the 'Fagus-Carpinus phase'. The fourth pollen zone (Is-4) is a new phase - one characterized by declining forest cover and the prevalence of taxa introduced to Colchis during the Soviet period - which we term the 'Modern Invasive Phase'.

\section{The Castanea phase (pollen zone Is-1)}

Chestnut (Castanea sativa) has survived repeated glacial periods in southern Europe, Colchis, Lenkoran and Eastern Georgia (Huntley and Birks, 1983; Zohary and Hopf, 1993; Dolukhanov, 1966). It typically has low pollen production and so 
proportions greater than 5\% generally signify its local presence (Huntley and Birks, 1983). Castanea pollen percentages show considerable spatial heterogeneity and attain $32-59 \%$ of dryland pollen in the Ispani diagrams prepared by Dokturovskii (1936). In the new Ispani-II diagram presented in this paper, Castanea percentages reach $85 \%$ (or $70 \%$ with Alnus in the pollen sum), representing chestnut-dominated vegetation.

Today chestnut forests have a very restricted distribution in Georgia (Figure 1), having been adversely affected by timber felling and fungal diseases since ancient times (Dolukhanov, 1966). Their current distribution is confined to the sides of steep valleys in the foothills ringing the lowlands. Castanea sativa grows alongside other deciduous trees, especially in mixed forests dominated by Fagus orientalis and Carpinus betulus (Nakhutsrishvili, 1999). But it appears that the mid-Holocene forests at Ispani-II were dominated by chestnut alone, perhaps with an understorey of Rhododendron ponticum, Ilex colchica, Sambucus nigra, Viburnum opulus and ferns including Polypodium, Pteridium and Anogramma. Lianas such as Hedera helix, $H$. colchica, Humulus lupulus and Vitis vinifera also appear to have been present. Most of these taxa are insect-pollinated and therefore under-represented palynologically. The presence of Cannabis-type, Asteraceae-Cichorioideae, Lamiaceae and a few Cerealia-type pollen grains through the Castanea phase suggests that while chestnut trees dominated the landscape, it was not entirely covered by forest - in fact, trees other than chestnut appear to have been few. 
Comparing the Ispani-II pollen record with others from Colchis, we see that the Castanea phase is inconsistently represented, both in age and magnitude (Figure 4). Maximum chestnut percentages occur in sediments dated prior to $6200 \mathrm{cal}$. BP in the Imnati record (Neishtadt et al., 1965), declining at least 2000 years earlier than at Ispani-II. Instead, Quercus, Carpinus and Ulmus are important between 6200 and 2100 cal. BP. At Supsa, Pterocarya dominates pollen spectra of the period encompassed by the Castanea phase at Ispani-II (Kvavadze, 1982). The Anaklia record (Serebryannyi et al., 1984) does show an increase in Castanea between 5300 and $3000 \mathrm{cal}$. BP, but its magnitude is insignificant compared to that of coniferous tree species: Pinus, Picea and Abies.

Castanea dominates the Kobuleti-39 record (Kvavadze and Dzheiranashvili, 1987), from the Choloki estuary near the Ispani bogs, until the expansion of Pterocarya in about 1000 cal. yr BP (based on the Ispani-II chronology). A diagram from near Sukhumi (Kvavadze and Dzheiranashvili, 1989) demonstrates that Castanea replaced Fagus and Abies some 8000-9000 years ago and remained dominant for the remainder of the Holocene. Significantly, at the mountain site of Chamlukh (1650 m elevation), Castanea peaks after 3700 cal. yr BP (Yazvenko, 1994). Lowland diagrams by Sluka (1973) show that the Castanea phase lasted until 4800-4400 cal. yr BP near the seaside Nabada and Churia bogs. In our diagram, the Castanea phase ended abruptly around 4500 cal. yr BP. 
The close of the Castanea phase has been traditionally aligned with the end of the Atlantic 'climatic optimum’ (Neishtadt, 1957; Sluka, 1973; Kvavadze, 1982; Dzhanelidze, 1980), but radiocarbon dating indicates that the phase was not regionally-synchronous (Figure 4). Either the dates are wrong, or the composition of mid-Holocene forests in Colchis was not solely determined by climate.

\section{The transitional phase (pollen zone Is-2)}

The transitional phase is also variable in its timing and magnitude. Even in the original Ispani-I diagram prepared by Dokturovskii (1936), Castanea percentages are much more consistent than in our Ispani-II diagram. In the latter, chestnut declines rapidly and continues to diminish, whereas in Ispani-I, chestnut remains important throughout the transitional phase.

The new diagram presented here shows that the vegetation around the IspaniII bogs during the transitional phase probably had fewer trees and a greater shrub cover than the Castanea phase. From 4500 to about 3000 cal. yr BP, the Ispani-II landscape was dominated by Alnus barbata, growing in swamp forests around extensive marshlands. There was also a significant shrubby component in the understorey, including Frangula alnus, Viburnum opulus and other shrubs that are found in coppiced Alnus back-swamp forests in Colchis today (Denk et al., 2001). The surrounding forests were a typically Colchic mix of Quercus hartwissiana, Fraxinus excelsior, Fagus orientalis, Castanea sativa, Carpinus betulus, Zelkova 
carpinifolia, Corylus avellana and other species. Some of these species could have grown in elevated parts of the Alnus back-swamp forests also.

At some time around $3000 \mathrm{cal} . \mathrm{yr} \mathrm{BP}$, the landscape around Ispani-II changed. The extent of Alnus barbata diminished, leaving open areas to be colonized by Frangula alnus and other shrubs. Herbs of open ground also increased - Poaceae, Asteraceae, Apiaceae and a suite of non-arboreal pollen are much better represented during the second half of the transitional phase. More than any previous period, this phase was marked by the increasing role of anthropogenic indicators (sensu Behre, 1986): Triticum-type, Secale-type, Rumex, Plantago lanceolata-type, P. major-type and Polygonum aviculare-type. The decline of Alnus and concomitant peak in grass pollen is accompanied by an enormous increase in charcoal concentrations, almost certainly indicating the extensive and repeated occurrence of fire.

\section{The Fagus-Carpinus phase (pollen zone Is-3)}

The Fagus-Carpinus phase begins at much the same time at Ispani-II bog as it does at Imnati, Nabada and Churia, around 2000 cal. yr BP. It is absent from Anaklia and Supsa, and appears somewhat later in the Kobuleti-39 diagram (Kvavadze, 1982; Serebryannyi et al., 1984; Kvavadze and Dzheiranashvili, 1987). At Ispani-II, it is characterized by the rapid expansion of Carpinus betulus and Fagus orientalis, and the appearance of Olea europaea, Juglans and Pterocarya. Many of the anthropogenic indicators (e.g. Plantago lanceolata-type, P. major-type, Rumex) that appeared during the transitional phase continue through the Fagus-Carpinus phase. 
Fagus orientalis occurs in Colchis only in better-drained places, being unable to tolerate the boggy soils of Alnus-dominated swamps (Denk et al., 2001). Beech forests are nowadays the most widely-distributed forest type in Colchis, from sealevel up to about $2300 \mathrm{~m}$. Carpinus betulus is the most common subdominant in Caucasian beech forests (Nakhutsrishvili, 1999). According to Denk et al. (2001), Carpinus is able to tolerate swampy soils in Colchis, but is always subordinate to Alnus and Pterocarya in such situations. The Ispani-II pollen record indicates that Fagus-Carpinus forests replaced Castanea sativa and mixed oak forests as well as areas of open land. Pterocarya fraxinifolia first appears in the record about 2000 cal. yr BP, but expands considerably in the Ispani area around 1000 cal. yr BP, invading areas of Alnus swamp forest. After the Pterocarya invasion, water tables may have lowered slightly, allowing the re-establishment of Fraxinus and Quercus in suitable habitats. The Fagus-Carpinus phase was a time of relative vegetation stability. According to the DCA results, it was also the phase with the greatest forest cover.

\section{The modern invasive phase (pollen zone Is-4)}

History records that much of the Colchis lowland was drained, deforested and turned over to plantations as a result of forced agricultural collectivization beginning in the 1930s (Badenkov et al., 1990; Ketskhoveli, 1959; Gulisashvili, 1964). Under the Soviet Union's increasingly insular economic structure, frost-free areas such as the Black Sea coast suddenly became valuable for their unique ability to satisfy demand for 'subtropical' crops such as tea and citrus from within. Broad-scale 
landscape modification is clearly represented in pollen evidence from this phase.

Both Cryptomeria japonica and Ambrosia, plants introduced to Colchis at some time during the 1930s (Sharadze, 1987; Dr Zurab Manvelidze, Batumi Botanical Garden, pers. comm.), dominate pollen spectra from the modern invasive phase. The destruction of lowland forests is likewise recorded (Figure 3) as a decline in forest pollen taxa - Fagus, Carpinus, Quercus, Ulmus and Fraxinus - and also diminishing proportions of swamp taxa such as Alnus and Pterocarya as wetlands were drained and turned over to mechanized agriculture. Based on the appearance of marker taxa such as Ambrosia and historical records of early-mid $20^{\text {th }}$ century deforestation in lowland Colchis, we believe that the modern invasive phase began in the 1930s, rather than in the post-Soviet period (i.e. after 1991) as suggested by Kaffke et al. (2002). It remains to be seen whether this new phase can be identified palynologically at other sites along the Black Sea coast of Georgia.

\section{Human impact}

It is difficult to ignore humans in any history of Colchis. The region was well known to Ancient Greeks through the legendary voyage of Jason and the Argonauts to capture the Golden Fleece from King Aeëtes, as well as the story of Prometheus, whom Zeus had chained to the Caucasus for giving fire to humankind. Colchis is associated with the names Strabo, Hippocrates, Herodotus, Xenophon and Pompey soldiers, philosophers and adventurers for whom the land held a great fascination. By the $6^{\text {th }}$ century BC, Ionian Greeks had established colonies right along the Black Sea 
coast (Braund, 1994; Tsetskhladze and Treister, 1995). These settlements consisted of clusters of log houses sited atop artificial mounds within the wetlands: "People spend their whole lives in the swamps and their wooden or reed houses are built on the water" (Pseudo-Hippocrates, Airs, Waters, Places, quoted in Tsetskhladze, 1997: 122). Such unusual settlements may have had a very peculiar impact on the vegetation.

The geographer Strabo (64 BC - 25 AD) describes Colchis as "well wooded with all kinds of timber" (Strabo, Geography 11.2. 15). Wood was the natural construction material for the lowland Colchians, who extensively used Quercus, Castanea, Buxus, Fagus, Alnus and Fraxinus for housing, tools and utensils from the Bronze Age onwards (Apakidze, 1991; Tsetskhladze, 1997). Amongst the timbers of Colchis, Quercus and Castanea are valued for their rot-resistance and were probably most prized for construction of houses, boats, bridges, piles and other purposes (Berg, 1950; Huntley \& Birks, 1983). One might ask whether the economy of ancient Colchis exerted a selective influence over forest composition. For instance, chestnut trees may have been, at times, carefully conserved for their fruits (e.g. during the Bronze Age), while, at other times, felled for their timber, depending on people's changing needs, technology and cultural affinities.

Despite extensive archaeological investigations of coastal settlements, a clear picture of their agricultural economy is yet to emerge. Historical sources are hardly more helpful. Pseudo-Hippocrates tells us that the Colchians' crops were meagre on 
account of the perpetual rain, "distinguished by their flabbiness... and do not ripen properly" (quoted in Tsetskhladze, 1997: 122). Strabo, in contrast, informs us that, "the country is excellent both in respect to its produce... and in respect to everything that pertains to ship building; for it not only produces quantities of timber but also brings it down on rivers. And the people make linen in quantities, and hemp, wax, and pitch" (Strabo, Geography 11. 2. 17). From archaeology we know that wheat, although found in many Colchian sites (Lordkipanidze, 1994), could barely withstand the damp coastal climate and was often imported from neighbouring lands (Braund, 1994: 55; Tsetskhladze, 1997). Millet was perhaps the only grain grown in the boggy parts of Colchis in antiquity (Braund, 1994), and laborious drainage works were necessary to increase the ground available for crop cultivation (Tsetskhladze, 1997). Despite this, agriculture held an important economic and symbolic place in the Colchian kingdom (Lordkipanidze, 1994). Some have argued that Colchian lowland agriculture followed a 'slash and burn' or swidden model (Kushnareva, 1997), such is the rapidity of afforestation (cf. Berg, 1950: 195).

One could associate some form of slash-and-burn agriculture with the prominent charcoal peaks in the transitional phase of the Ispani-II pollen diagram. In an area with 2.5 metres of annual rainfall, it seems improbable that such fires occurred spontaneously. The composition of the vegetation obviously changed remarkably with the occurrence of frequent and widespread burning - alder swamp forest disappeared, light-demanding understorey plants proliferated and the cultivation of 
various agricultural plants increased. Considering the archaeological data, the swidden model here must encompass permanent settlements around which forests and open agricultural land were managed with the aid of fire. Archaeologists have noted the apparent decline of metallurgical production of axes and other implements coincident with Greek colonisation (Tsetskhladze and Treister, 1995). We suggest that this may have been a response to changing agro-forestry practices.

There is another possibility: that the charcoal record pertains to the wetland vegetation itself, and that the reeds and sedges themselves were burnt. This hypothesis has some merit when we remember that the settlements of the time were situated on mounds within the marshes, and that the people "seldom go on foot in the polis and emporium, but canoe up and down in dug-outs, for there are many canals" (Pseudo-Hippocrates, quoted in Braund, 1994: 49). Dense wetland vegetation could cause significant inconvenience to navigation, and setting it alight may have been the most effective means of its removal. Repeated fires would have also prevented the establishment of Sphagnum blanket bog. But as there is no way of accurately determining the source-area of the Ispani-II charcoal record, it remains unclear whether these significant fires were confined to the wetland itself or occurred more widely.

After 1900 cal. yr BP, when burning appears to have declined, both the settlements and agricultural lands around Ispani-II wetland were largely abandoned. This provided Fagus an opportunity to migrate from the mountains to colonize the 
lowlands, since it has difficulty invading closed forest (Huntley and Birks, 1983).

Pterocarya also began migrating slowly out of riverine refuges onto the coastal plain.

Castanea gradually disappeared from the coastal lowlands because of its dislike of waterlogged soils, its great economic value and susceptibility to disease when coppiced (Dolukhanov, 1966; Huntley and Birks, 1983). The Romans appear to have introduced olives and walnuts to cultivation in Western Georgia at this time, and throughout the ensuing millennia forest cover was denser than at any other period during the last 5600 years.

The landscape around Ispani-II remained in a state of relative stability from 1900 cal. yr BP until the $20^{\text {th }}$ century. Then forest cover was all but destroyed and replaced with plantations of tea, citrus, tung tree, Cryptomeria and others (Walter, 1974; Ketskhoveli, 1959). Many swamps were drained and the Ispani-I bog was cut extensively for peat (Joosten et al., 2003; Badenkov et al., 1990). All of these changes, of course, are the result of the broad-scale human impacts that accompanied Stalin's push for rapid agricultural development and collectivization beginning in the 1920s and 1930s.

\section{Sea level changes and peatland development}

Five-and-a-half thousand years ago, through the lower part of the Castanea phase, Ispani-II existed amongst alder swamps. A drying phase or a stagnant lagoon phase followed, around 5000 years ago $(875-800 \mathrm{~cm})$, wherein Trapa, Spirogyra, Ceratophyllum, Pediastum and Tetraploa were important. An overall decline in 
wetland taxa in the upper part of the Castanea phase, when taken with the low organic content of the sandy sediments, suggests that groundwater levels fell and the site was surrounded by well-drained alluvial flats up until 4500 cal. yr BP.

An abrupt rise in the water-table at the beginning of the transitional phase restored alder swamps to their former extent, and an increase in Callitriche, Iris pseudacorus-type and Potamogeton indicates the presence of a shallow open-water fen in the Ispani-II marshlands. The next stage $(600-500 \mathrm{~cm})$ began mid-way through the transitional phase with the retreat of Alnus swamp forest and the short-lived appearance of Sphagnum, the latter swiftly yielding to grasses, sedges and Osmunda, indicating a disturbed sedge or reed swamp.

This stage ended around 1900 cal. yr BP with a second abrupt rise in watertables, initiating the growth of Sphagnum blanket mire (Fagus-Carpinus phase). At first this was probably paludal species like Sphagnum palustre, but following the Pterocarya invasion around 1000 cal. BP, peat made of hummock species (e.g. Sphagnum imbricatum and S. papillosum) accumulated and continued forming rapidly up to the present, modern invasive phase.

During the period covered by the Ispani-II pollen diagram, three major relative sea level changes occurred: the New Black Sea transgression between 6500 and 4500 cal. yr BP; the Phanagorian regression from 4500 to 2000 cal. yr BP; and the Nymphaean transgression of 2000-1000 cal. yr BP (Chepalyga, 1984). In Colchis, the timing, amplitude and impact (Figure 5) of these events diverges to some extent from 
the regional pattern because of rapid tectonic subsidence and local geomorphology (Kaplin and Selivanov, 2004; Tvalchrelidze et al., 2004; Dzhanelidze, 1980).

Archaeological evidence for coastal subsidence and sea level change comes from the Ispani peatland itself. A Neolithic to middle Bronze Age settlement was uncovered during the excavation of a drainage canal in the 1970s (Mikeladze and Baramidze, 1976; Matchutadze, 2004). This settlement was buried beneath four metres of peat and wooden dwellings were well preserved in the waterlogged, anoxic conditions (Dzhanelidze, 1980). Interestingly, the earlier dwellings at Ispani were built directly on the ground, but later houses were supported upon wooden piles. This trend is reflected in several late $3^{\text {rd }}$ millennium $\mathrm{BC}$ coastal sites in Colchis (Tsetskhladze, 1997). Dzhanelidze (1980) considers it a reaction to changing sea levels during the New Black Sea transgression, which built up new coastal dunes, impeding the drainage of the Colchis lowland and leading to extensive paludification and peat-bog formation. Eventually rising groundwater overwhelmed these settlements on piles, and they were abandoned in favour of more elevated ground (Dzhanelidze, 1980; Matchutadze, 2004; Tsetskhladze, 1997).

The sudden demise of Castanea-dominated forests around $4500 \mathrm{cal}$. BP at Ispani-II is most likely the result of rising water-tables at the end of the New Black Sea transgression, since chestnut is very sensitive to changes in soil moisture (Grove and Rackham, 2001). Likewise, the abandonment of coastal settlements and expansion of Pterocarya during the Fagus-Carpinus phase can be linked to the 
Nymphaean transgression between 2000 and 1000 cal. BP. At Ispani-II, sea level rises had immediate and lasting consequences for the coastal environment and vegetation (Figure 5), whereas marine regressions had little impact. Paludification was thus the dominant impetus for late Holocene vegetation change in lowland Colchis.

It must be remembered, however, that the Colchian people had been manipulating the hydrology of the marshy lowlands by constructing embankments, drains and artificial hillocks since the $3^{\text {rd }}$ millennium BC (Kushnareva, 1997; Tsetskhladze, 1994). Inadvertently, these drainage works, along with burning and deforestation, created ideal conditions for the growth of Sphagnum mosses. Like many European blanket mires, the Sphagnum peat of Ispani-II is underlain by a charcoal layer that provides not only a legacy of anthropogenic deforestation and burning, but may also have altered mire hydrology to favour Sphagnum growth (Moore, 1993). On the balance of archaeological, geomorphological and palynological evidence, there are grounds for regarding the Ispani Sphagnum bogs as cultural artefacts. It is perhaps no coincidence that the area of Colchis that had the greatest coastal population concentration during the $1^{\text {st }}$ millennium $\mathrm{BC}$ is also the area that subsequently developed the greatest area of Sphagnum bogs.

\section{Conclusions}

Based on the palynological evidence presented here, we recognize four stages of landscape change around Ispani-II: the chestnut-dominated open woods of the mid- 
Holocene Castanea phase, the shrubby, marshy landscapes of the transitional phase, the afforestation and stability of the beech-hornbeam phase, and the deforested agricultural landscapes of the $20^{\text {th }}$ century. Our results call into question the idea that the Black Sea coast was entirely and densely forested throughout the Holocene.

In a perpetually-moist climate, such as that of southern Colchis, Holocene fluctuations in temperature and precipitation may have had minor impact on forest composition. If we accept that dense forests dominate lowland Colchis in the absence of disturbance, then forest successional changes would have occurred through gapphase regeneration, a process of gradual replacement rather than sudden change. It seems unlikely that the rapid and fundamental vegetation changes revealed by the Ispani-II material were determined solely by regional climatic variations. This is supported by the asynchronous limits of the 'Castanea' phase of Holocene vegetation development in the Colchis lowland.

Instead, we argue that vegetation dynamics were strongly influenced by relative sea level changes and human activities. The Bronze Age rise and fall of chestnut woods undoubtedly reflected groundwater variations controlled by coastal subsidence and sea level change. Throughout the $1^{\text {st }}$ millennium $\mathrm{BC}$, the axe and fire were the main agents of vegetation change; in the hands of villagers and farmers, these tools were sufficient to alter the direction of climate-driven successional pathways. But, in turn, the inexorable transgression of the Black Sea stamped its 
mark on the vegetation of Colchis, and not until the tractor replaced the ox in the $20^{\text {th }}$ century do we once again see the ascendancy of human impact.

\section{Acknowledgements}

We thank Mr Matthias Krebs (Greifswald University) and Dr Izolda Machutadze (Batumi Botanical Garden) for providing the Ispani-II material and assisting with fieldwork. Thanks also to Dr Gocha Tsetskhladze (University of Melbourne) for enlightening discussions on archaeology, to Dr Giorgi Arabuli (Botanical Department, Georgian State Museum) for botanical advice, and to Maradi and his family in Kobuleti for their hospitality. We are grateful to the Australian Institute of Nuclear Science and Engineering for funding AMS dates and to our reviewers for their helpful comments on the manuscript.

\section{References}

Akhalkatsi, M., Lorenz, R., Matchutadze, I. and Mosulishvili, M. 2004: Spiranthes amoena - a new species for Flora of Georgia. Journal Europäischer Orchideen 36, 745-754.

Aksu, A. E., Hiscott, R. N. and Yaşar, D. 1999: Oscillating Quaternary water levels of the Marmara Sea and vigorous outflow into the Aegean Sea from the Marmara Sea-Black Sea drainage corridor. Marine Geology 153, 275-302.

AN GSSR (Akademiia Nauk Gruzinskoi SSR). 1964: Atlas Gruzinskoi SSR [Atlas of the Georgian SSR]. Tbilisi: GUGK (in Russian).

Apakidze, J. B. 1991: Tsentralnaiia kolkhida v epokhy pozdnii bronzy-rannyevo zheleza (Central Colchis in the late Bronze and early Iron ages). Tbilisi: Metsniereba.

Atanassova, J. 2005: Palaeoecological setting of the western Black Sea area during the last 15000 years. The Holocene 15, 576-584. 
Badenkov, Y. P., Borunov, A. K., Mandych, A. F., Romashkevich, A. I. and Targulian, V. O. 1990: Caucasia. In Turner, B. L., II, editor, The Earth as transformed by Human Actions: global and regional changes in the biosphere over the past 300 years, Cambridge: Cambridge University Press, 513-531.

Ballard, R. D., Coleman, D. F. and Rosenberg, G. D. 2000: Further evidence of abrupt Holocene drowning of the Black Sea shelf. Marine Geology 170, 253-261.

Behre, K.-E. 1986: The interpretation of anthropogenic indicators in pollen diagrams. Pollen et Spores 23, 225-245.

Bengtsson, L. and Enell, M. 1986: Chemical analysis. In Berglund, B. E., editor, Handbook of Holocene Palaeoecology and Palaeohydrology, Chichester: John Wiley \& Sons, 423-451.

Bennett, K.D. 2002: PSIMPOLL 4.10 (computer programme). Uppsala Universitet: Department of Earth Sciences.

Berg, L. S. 1950: Natural Regions of the U.S.S.R. New York: Macmillan.

Birks, H. J. B. and Gordon, A. D. 1985: Numerical methods in Quaternary pollen analysis. London: Academic Press.

Braund, D. 1994: Georgia in Antiquity. Oxford: Clarendon Press.

Chepalyga, A. L. 1984: Inland sea basins. In Velichko, A. A., editor, Late Quaternary Environments of the Soviet Union, Minneapolis: University of Minnesota Press, 229-247.

Clark, R. L. 1982: Point count estimation of charcoal in pollen preparations and thin sections of sediments. Pollen et Spores 24, 523-535.

Denk, T., Frotzler, N. and Davitashvili, N. 2001: Vegetational patterns and distribution of relict taxa in humid temperate forests and wetlands of Georgia (Transcaucasia). Biological Journal of the Linnean Society 72, 287-332.

Dokturovskii, V. S. 1931: O torfianikakh Zakavkaz'ia [On the peatbogs of Transcaucasia]. Torfianoe Delo 2, 29-32 (in Russian).

Dokturovskii, V. S. 1936: Materialy po izucheniiu torfianikov Zakavkaz'ia [Materials for the study of Transcaucasian peatbogs]. Pochvovedenie 2, 183-202 (in Russian).

Dolukhanov, A. G. 1966: Rastitel'nostii Pokrov [Vegetation Cover]. In Kavkaz, Moscow: Nauka, 223-251 (in Russian).

Dzhanelidze, C. P. 1980: Paleogeografiia Gruzii v Golotsene [Holocene Palaeogeography of Georgia]. Tbilisi: Metsniereba (in Russian).

Fedorov, P. V. 1988: The problem of changes in the level of the Black Sea during the Pleistocene. International Geology Review 30, 635-641. 
Görür, N., Çağatay, M. N., Emre, Ö., Alpar, B., Sakınç, M., İslamoğlu, Y., Algan, O., Erkal, T., Keçer, M., Akkök, R. and Karlık, G. 2001: Is the abrupt drowning of the Black Sea shelf at 7150 yr BP a myth? Marine Geology 176, 65-73.

Grove, A. T. and Rackham, O. 2001: The nature of Mediterranean Europe: an ecological history. New Haven: Yale University Press.

Gulisashvili, V. Z. 1964: Prirodnye zony i estestvenno-istoricheskie oblasti Kavkaza [Natural zones and eco-historical regions of the Caucasus]. Moscow: Nauka.

Gvilava, M., editor. 1996: State of the Environment Georgia. Tbilisi: Geoinformation Center (http://enrin.grida.no//htmls/georgia/soegeor/hp_soege.htm)

Hill, M. O. 1979: DECORANA: a FORTRAN program for detrended correspondence analysis and reciprocal averaging. Ithaca, NY: Cornell University.

Huntley, B. and Birks, H. J. B. 1983: An Atlas of Past and Present Pollen Maps for Europe: 0 - 13000 years ago. Cambridge: Cambridge University Press.

Joosten, H., Kaffke, A. and Matchutadze, I. 2003: The mires of the Kolkheti lowlands (Georgia). International Mire Conservation Group Newsletter 2003/3, 19-23.

Kaffke, A., Matchutadze, I., Couwenberg, J. and Joosten, H. 2002: Early 20th century Russian peat scientists as possible vectors for the establishment of Calluna vulgaris in Georgian Sphagnum bogs. Suo 53, 61-66.

Kaplin, P. A. and Selivanov, A. O. 2004: Lateglacial and Holocene sea level changes in semi-enclosed seas of North Eurasia: examples from the contrasting Black and White Seas. Palaeogeography, Palaeoclimatology, Palaeoecology 209, 19-36.

Ketskhoveli, N. 1959: Sakartvelos Mtsenareuli Sapari [Georgia's vegetation cover]. Tbilisi: SSSR Metsnierebata Akademiis Gamomtsemloba (in Georgian).

Kikividze, Z. and Ohsawa, M. 2001: Richness of Colchic vegetation: a comparison between refugia of south-western and East Asia. BMC Ecology 1, 6.

Kolakovskii, A. A. 1961: Rastitel'nyi mir Kolkhidi [Plant world of Colchis]. Moscow: Izdat. Mosk. Univ. (in Russian).

Kushnareva, K. K. 1997: The Southern Caucasus in prehistory. Philadelphia: University of Pennsylvania.

Kvavadze, E. V. 1982: Novye dannye po stratigrafii i paleogeografii Golotsena Kolkhidskoi nizmennosti [New data for the stratigraphy and Holocene palaeogeography of the Colchis lowland]. In Chetvertichnaia Sistema Gruzii, Tbilisi: Metsniereba, 123-130 (in Russian).

Kvavadze, E. V. and Dzheiranashvili, V. G. 1987: Palinologicheskaia kharakteristika verkhnepleistotsenovykh i golotsenovykh otlozhenii Kobuleti [Palynological 
characteristics of Upper Pleistocene and Holocene sediments from Kobuleti]. Soobshch. AN GSSR 127, 189-192 (in Russian).

Kvavadze, E. V. and Dzheiranashvili, V. G. 1989: Palinologicheskaia kharakteristika Golotsenovykh otlozhenii shel'fa Chernogo Moria v raione Sukhumi [Palynological characteristics of Holocene Black Sea shelf sediments in the Sukhumi area]. Soobshch. AN GSSR 135, 201-204 (in Russian).

Lordkipanidze, O. D. 1994. Recent discoveries in the field of classical archaeology in Georgia. Ancient Civilizations 1(2), 127-168.

Matchutadze, I. 2004: The evidence for prehistoric climate and ecology in the Ispani excavations. The Black Sea region: past, present and future. Abstracts, British Academy Black Sea Initiative Conference, Istanbul Technical University: 1416 October 2004 (www.biaa.ac.uk/blackseaconference).

Mikeladze, T. K. and Baramidze, M. B. 1976: O nekotorykh itogakh polevykh issledovanii v Kolkhidskoi nizmennosti v zonakh novostroiek (Some results of fieldwork in the Colchis lowland construction zone). In Arkheologicheskii issledovaniia na novostroikakh Gruzinskoi SSR, Tbilisi: Metsniereba, 95-101 (in Russian).

Moore, P. D. 1993: The origin of blanket mire, revisited. In Chambers, F. M., editor, Climate change and human impact on the landscape, London: Chapman and Hall, 217-224.

Moore, P. D., Webb, J. A. and Collinson, M. E. 1991: Pollen Analysis. Oxford: Blackwell Science Publishers.

Mudie, P., Rochon, A., Aksu, A. and Gillespie, H. 2002: Dinoflagellate cysts, freshwater algae, and fungal spores as salinity indicators in Late Quaternary cores from Marmara and Black Seas. Marine Geology 190, 203-231.

Nakhutsrishvili, G. S. 1999: The vegetation of Georgia (Caucasus). Braun-Blanquetia $15,1-68$.

Neishtadt, M. I. 1957: Istoriia lesov i paleogeografiia SSSR v Golotsene [Forest history and Holocene palaeogeography of the USSR]. Moscow: Izdat. AN SSSR (in Russian).

Neishtadt, M. I., Khotinskiy, N. A., Devirts, A. L. and Markova, N. G. 1965: Imnatskoe boloto, Gruzinskaia SSR [Imnati bog, Georgian SSR]. In Paleogeografiia i khronologiia verkhnego pleistotsena i golotsena po dannym radiouglerodnogo metoda, Moscow: Nauka, 105-112 (in Russian).

Oksanen, J. and Minchin, P. 1997: Instability of ordination results under changes in input data order: explanations and remedies. Journal of Vegetation Science 8, 447-454. 
Röhrig, E. 1991: Deciduous forests of the Near East. In Röhrig, E. and Ulrich, B., editors, Temperate Deciduous Forests (Ecosystems of the World, vol. 7), Amsterdam: Elsevier, 527-537.

Rübel, E. A. 1914: The forests of the western Caucasus. Journal of Ecology 2, 39-42.

Ryan, W. B. F., Pitman, W. C., III, Major, C. O., Shimkus, K., Moskalenko, V., Jones, G. A., Dimitrov, P., Gorür, N., Sakinç, M. and Yüce, H. 1997: An abrupt drowning of the Black Sea shelf. Marine Geology 138, 119-126.

Serebryannyi, L. R., Margalitadze, N. A., Janelidze, C. P., Gei, N. A., Ilves, E. O., Skobeeva, E. I., Vinievskaya, E. M. and Orlov, A. V. 1984: Pozdne- i poslelednikovaia istoriia fitolandshaftov Kolkhidy [Late- and post-glacial history of the phyto-landscapes of Colchis]. Soobshch. AN GSSR, ser. biolog. 10, 5 (in Russian).

Sharadze, N. N., editor. 1987: Derevia i kustarniki Batumskogo botanicheskogo sada: annotirovannii spisok [Trees and shrubs of the Batumi Botanical Garden: an annotated list]. Tbilisi: Metsniereba (in Russian).

Shatilova, I. I. and Mchedlishvili, N. S. 1980: Palinologicheskie kompleksy Chaudinskikh otlozhenii zapadnoi Gruzii i ikh stratigraficheskoe znachenie [Palynological complexes of Western Georgian Chaudian deposits and their stratigraphic significance]. Tbilisi: Metsniereba (in Russian).

Sluka, V. P. 1973: Palinologicheskie i litologo-fatsial'nye issledovaniia golotsenovykh torfianykh otlozhenii Kolkhidskoi nizmennosti [Palynological and litho-facies analysis of Holocene peat sediments of the Colchis lowland]. In Palinologiia golotsena i marinopalinologia, Moscow: Nauka, 53-58 (in Russian).

Strabo 2000: Geography (Books 10-12, translated by H. L. Jones). Cambridge, Massachusetts: Harvard University Press.

Stuiver, M. and Reimer, P. J. 1993: Extended ${ }^{14} \mathrm{C}$ database and revised CALIB radiocarbon calibration program. Radiocarbon 35, 215-230.

Tarasov, P. E., Volkova, V. S., Webb, T., III, Guiot, J., Andreev, A. A., Bezusko, L. G., Bezusko, T. V., Bykova, G. V., Dorofeyuk, N. I., Kvavadze, E. V., Opisova, I. M., Panova, N. K. and Sevastyanov, D. V. 2000: Last glacial maximum biomes reconstructed from pollen and plant macrofossil data from northern Eurasia. Journal of Biogeography 27, 609-620.

Tsetskhladze, G. R. 1994: Archaeological investigations in Georgia in the last ten years and some problems of the ancient history of the eastern Black Sea region. Revue des Études Anciennes 96, 385-414.

Tsetskhladze, G. R. 1997: How Greek colonists adapted their way of life to the conditions in Kolkhis. In Fossey, J. M., editor, Proceedings of the first 
international conference on the archaeology and history of the Black Sea, Amsterdam: J. C. Gieben, 121-136.

Tsetskhladze, G. R. and Treister, M. Y. 1995: The metallurgy and production of precious metals in Colchis before and after the arrival of the Ionians (towards the problem of the reasons for Greek colonisation). Bulletin of the Metals Museum 24, 1-32.

Tumajanov, I. I. 1971: Changes of the Great Caucasus forest vegetation during the Pleistocene and Holocene. In Davis, P. H., Harper, P. C. and Hedge, I. C., editors, Plant Life of South-West Asia, Edinburgh: Botanical Society of Edinburgh, 73-87.

Tvalchrelidze, M., Lebanidze, Z. and Jaoshvili, G. 2004: Eustatics of the Black Sea and sedimentation peculiarities during the last 20000 years (Georgian sector of the Black Sea). Shromata krebuli - Trudy GIN AN Gruzii, nov. ser. 119, 656-666.

Uchupi, E. and Ross, D. A. 2000: Early Holocene marine flooding of the Black Sea. Quaternary Research 54, 68-71.

van Geel, B. 1978: A palaeoecological study of Holocene peat bog sections in Germany and the Netherlands, based on the analysis of pollen, spores and macro- and microscopic remains of fungi, algae, cormophytes and animals. Review of Palaeobotany and Palynology 25, 1-120.

Walter, H. 1974: Die vegetation Osteuropas, Nord- und Zentralasiens. Stuttgart: Fischer.

Yazvenko, S. B. 1994: Holocene pollen record from a peatland in the West Caucasus, Abkhasia, Black Sea region. Journal of Paleolimnology 12, 65-74.

Zohary, D. and Hopf, M. 1993: Domestication of Plants in the Old World. Oxford: Clarendon Press. 


\section{Figure captions}

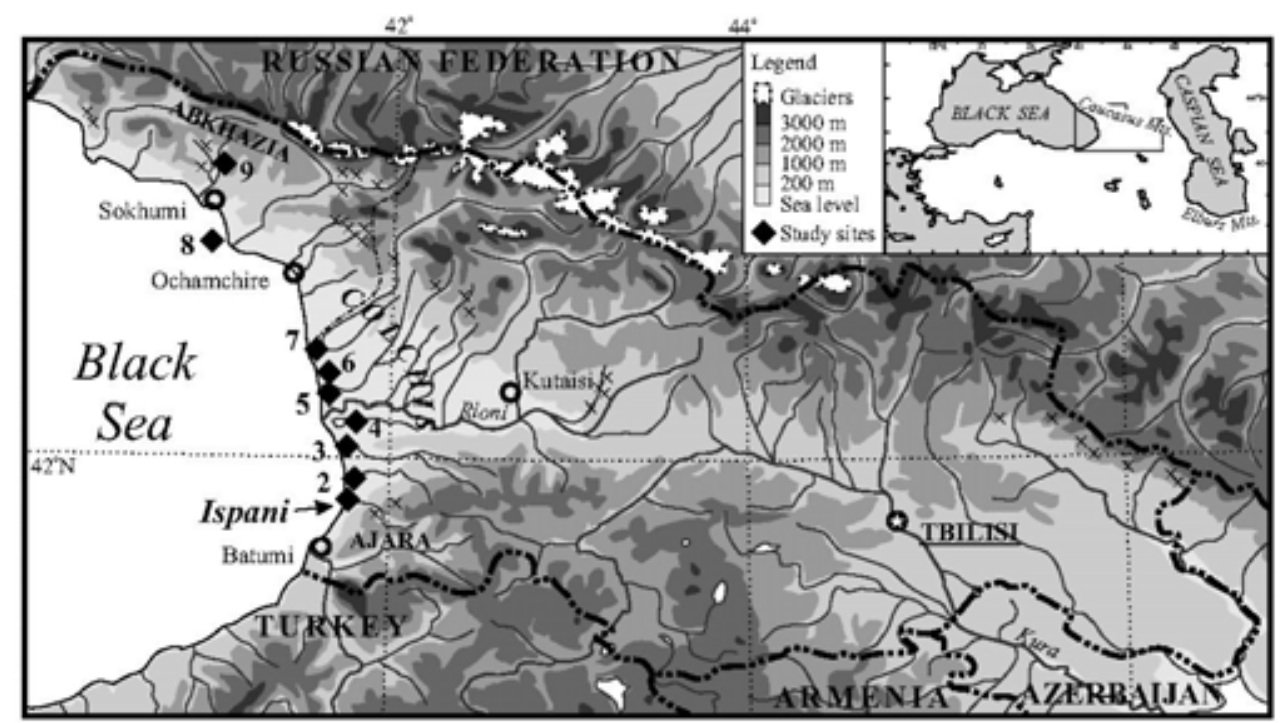

Figure 1 Topographic map of Georgia and the location of study sites mentioned in the text: 1- Ispani, 2- Kobuleti, 3- Supsa, 4- Imnati, 5- Nabada, 6Churia, 7- Anaklia, 8- Sukhumi, 9- Chamlukh. The symbol ' $\times$ ' denotes Castaneadominated forests (after Ketskhoveli, 1959; AN GSSR, 1964). 


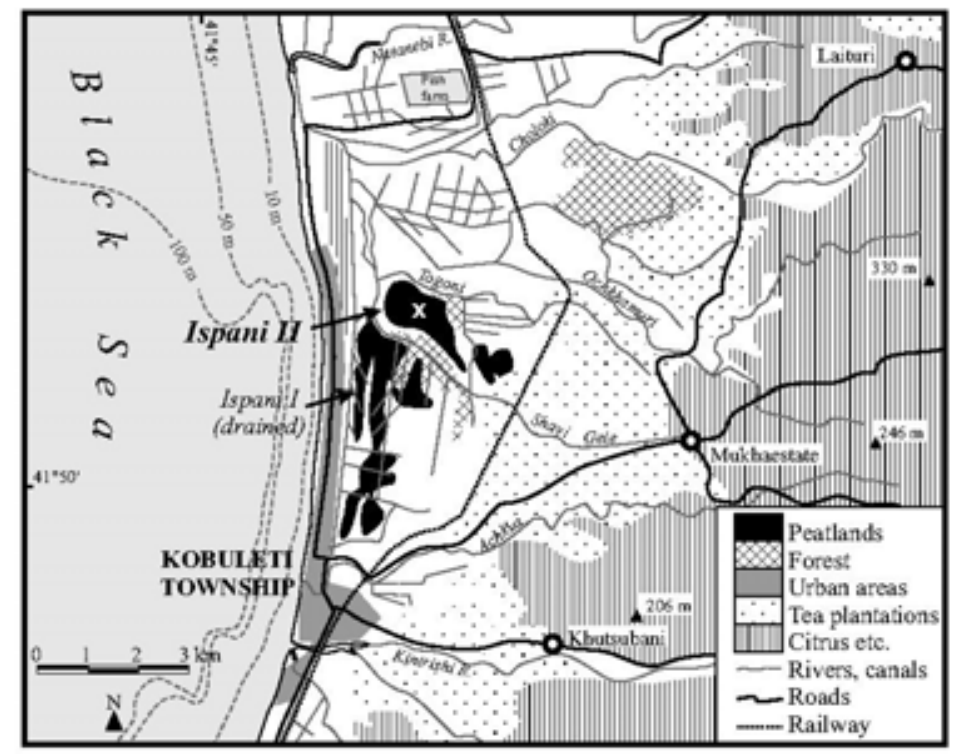

Figure 2 Land-use patterns around the Ispani bogs in the Kobuleti area (compiled from Gvilava, 1996, and 1:100000 GUGK topographic map series, 1975). The Ispani-II coring site is marked with an ' $\mathrm{x}$ '. 


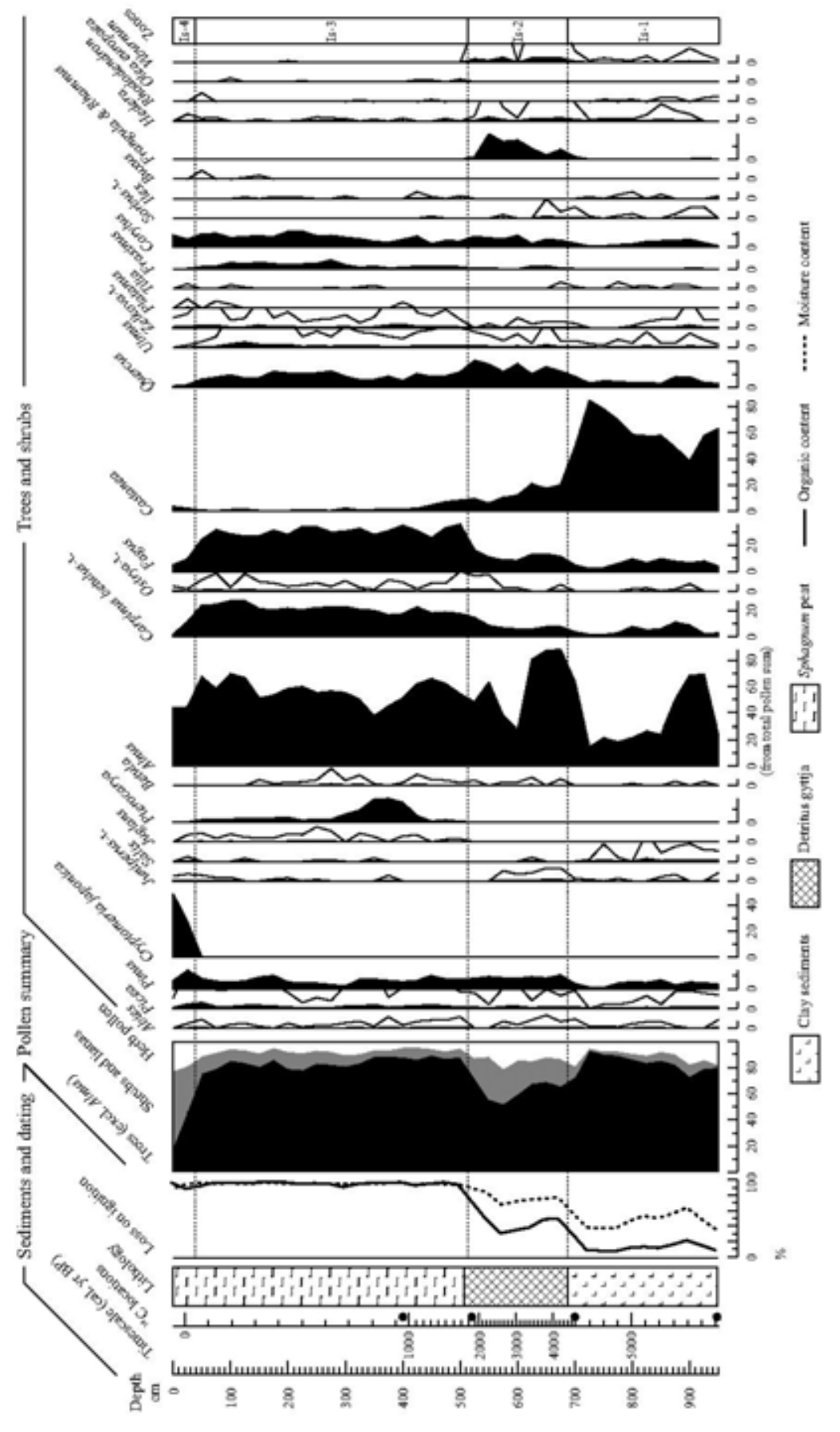

Figure 3a Ispani-II pollen diagram, showing percentages of major tree, shrub and liana pollen types, AMS dating locations and lithology. 


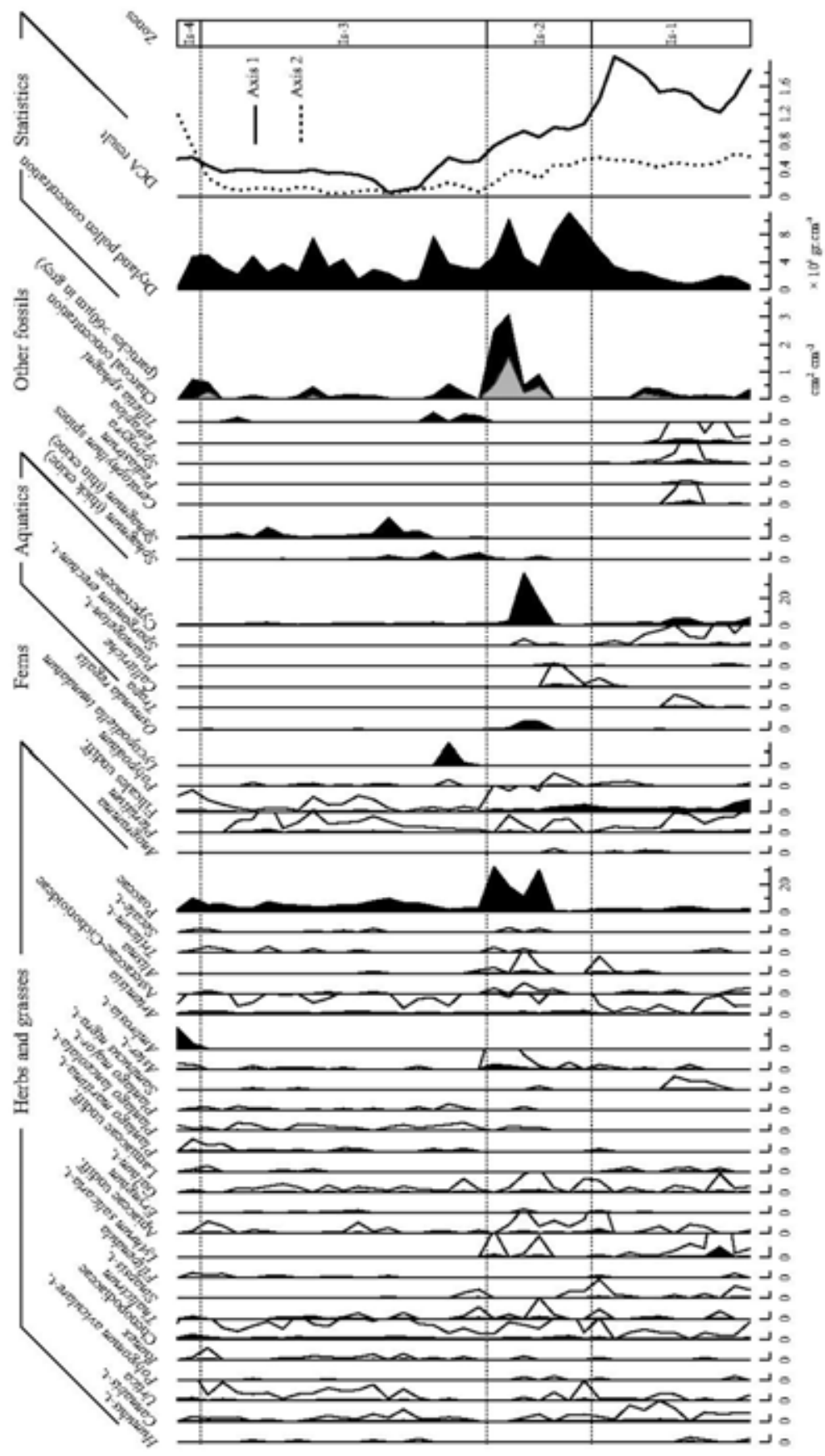

Figure 3b Ispani-II pollen diagram (continued), percentages of non-arboreal pollen types, charcoal concentrations and detrended correspondence analysis (DCA) results. 


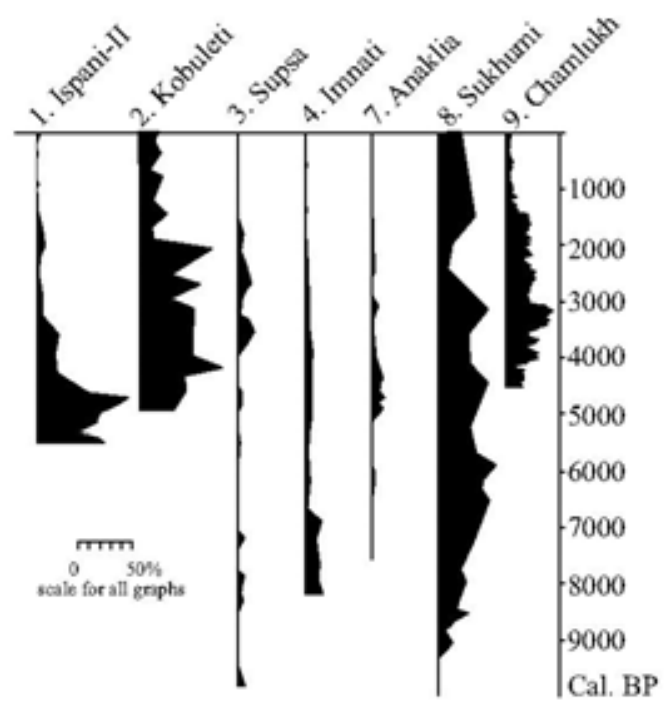

Figure 4 Comparison of Holocene chestnut (Castanea) pollen records from Colchis, arranged in south-north order (see Figure 1 for locations). Chronology based on linear interpolation of ${ }^{14} \mathrm{C}$ dates (data from this paper; Kvavadze, 1982; Kvavadze and Dzheiranashvili, 1987, 1989; Neishtadt et al., 1965; Serebryannyi et al., 1984; Yazvenko, 1994). 


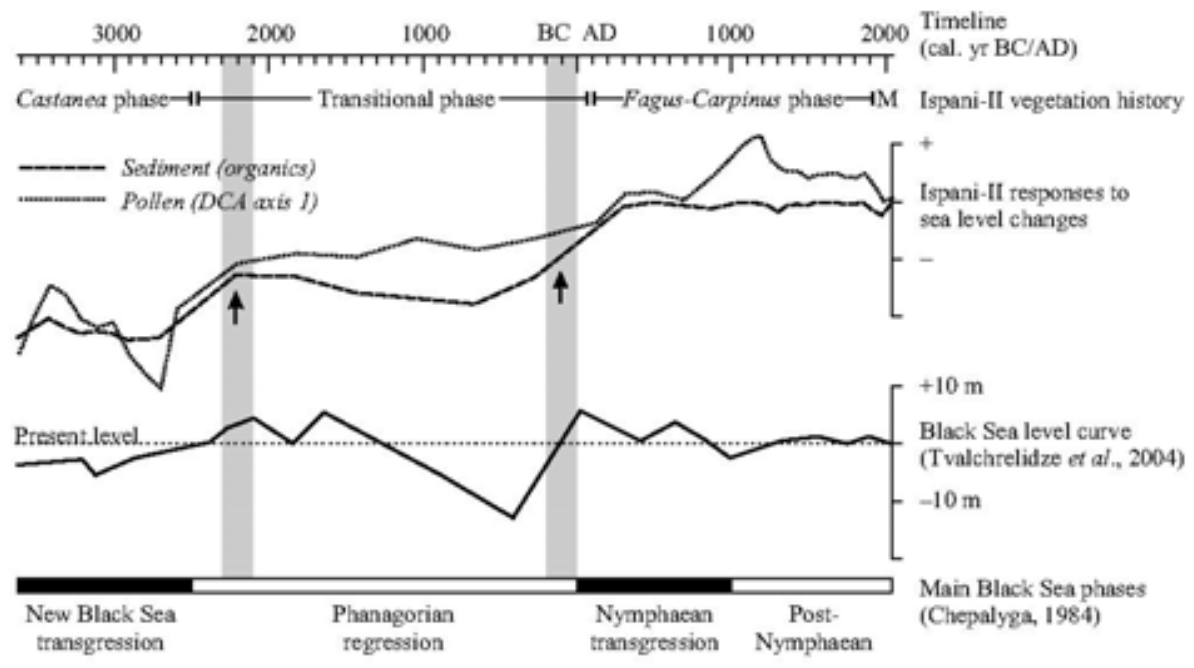

Figure 5 Sea level changes at Ispani-II and the abandonment of coastal settlements (arrows). Dashed curves represent sedimentary and biotic responses to coastal subsidence and sea level change, shown in relation to the sea level curve of Tvalchrelidze et al. (2004) for Georgia and Chepalyga's (1984) scheme for the Black Sea as a whole. $\mathrm{M}=$ modern invasive phase.

Table I Lithology of the Ispani-II core. Units correspond to zones in Figure 3.

\begin{tabular}{lllll}
\hline Unit(s) & Depth & Sediment & Colour & Macrofossils observed \\
\hline Is-3, Is-4 & $0-510 \mathrm{~cm}$ & Sphagnum peat & Brown to yellow & Sphagnum, Rhododendron, Molinia \\
Is-2 & $510-690 \mathrm{~cm}$ & Detritus gyttja & Black to brown & Alnus, graminoid remains, charcoal
\end{tabular}


Table II Radiocarbon determinations (AMS).

\begin{tabular}{llllll}
\hline $\begin{array}{l}\text { Sample } \\
\text { depth }(\mathrm{cm})\end{array}$ & $\begin{array}{l}\text { Lab } \\
\text { number }\end{array}$ & $\begin{array}{l}\text { Material } \\
\text { dated }\end{array}$ & $\begin{array}{l}\text { Uncalibrated age } \\
(\mathrm{yr} B P)\end{array}$ & $\begin{array}{l}\text { Calibrated age } \\
(\text { cal. yr BP*) }\end{array}$ & Calendar years \\
\hline $520-525$ & $\begin{array}{l}\text { Beta- } \\
209353\end{array}$ & $\begin{array}{l}\text { Woody } \\
\text { fragments }\end{array}$ & $1940 \pm 40$ & $1953-1816$ & 4 BC-134 AD \\
$695-700$ & $\begin{array}{l}\text { Beta- } \\
209354\end{array}$ & $\begin{array}{l}\text { Woody } \\
\text { fragments }\end{array}$ & $4060 \pm 40$ & $4646-4420$ & $2697-2471 \mathrm{BC}$ \\
$945-950$ & OZH-068 & Bulk carbon & $4900 \pm 50$ & $5738-5583$ & $3789-3634 \mathrm{BC}$ \\
\hline
\end{tabular}

* Two-sigma error range with highest (>90\%) probability (Method B of Stuiver and Reimer, 1993) 